Bureau of Transportation Statistics. Access:

http://www.bts.gov.

Produced by the Bureau of Transportation Statistics (BTS), this site is intended to supply facts and data to Congress, the Department of Transportation, federal and state agencies, metropolitan planning organizations, and the public. With a clear set of objectives centered on developing and disseminating data and information to users, this site provides a practical entry point to a wide range of statistical content.

\section{Bureau of Transportation Statistics}

Among the strengths of the site: a prominent link to TranStats, a portal to scores of databases; the National Transportation Library, with search and browse tools and access to a digital repository of technical, research, and policy documents; and the BTS bookstore, offering free downloads of new releases, and text box searching for older items, back to publication dates in the mid-1990s.

Because of the somewhat crowded fullpage layout of the site, BTS would seem to favor the experienced user, and lower division undergraduates will require some orientation to both the content and the interface. Users with a known item in mind will fare best, given the search options offered on every page, and prominent left and top navigation directs users to the site's main resources.

While the site features ready-made graphics and some interactivity in data display, it offers an additional convenience by providing data for download in a spreadsheet format. Users of statistical packages and GIS software will find the Excel format for most

Joni R. Roberts is associate university librarian for public services and collection development at Willamette University, e-mail: jroberts@willamette. edu, and Carol A. Drost is associate university librarian for technical services at Willamette University, e-mail: cdrost@willamette.edu sets convenient, and the scope of data on the site addresses a wide variety of information needs.

For example, if a patron is seeking data on passenger counts for domestic airline carriers, he or she could click on "Data and Statistics," then select "Aviation" from the "Data Finder" by mode menu, and then select "Summary Tables," filter by subject, then browse a list of results. From there, the patron could download the output or choose to query databases directly, with the option to create a custom table by selecting fields for analysis, and again download data in a spreadsheet format.

Though navigating the site presents the biggest challenge to new users, the site map, left menus, and site search tools are a welcome aid. Also helpful are the links to application plug-ins offered at the bottom of the page. The site is updated daily with helpful information about pending data and publication releases. Recommended for librarians, faculty, and students somewhat familiar with transportation data and experience querying databases.-Jeremy Donald, Trinity University,jdonald@trinity.edu

NOAA/ESRL Global Monitoring Division. $A c$ -

cess: http://www.cmdl.noaa.gov.

If Al Gore's film, An Inconvenient Truth, has brought global warming even a little bit more into our collective consciousness, here is one of the many U.S. government Web sites that helps explain the science behind it. The Global Monitoring Division (GMD) is part of the National Oceanic and Atmospheric Administration's (NOAA) Earth System Research Laboratory, which was created by combining units after a reorganization of NOAA in 2005.

GMD's mission is to "observe and understand, through accurate, long-term records of atmospheric gases, aerosol particles, and solar radiation, the Earth's atmospheric system controlling climate forcing, ozone 
depletion and baseline air quality, in order to develop products that will advance global and regional environmental information and services."

GMD has three major areas of focus: "Climate Forcing," "Ozone Depletion," and "Baseline Air Quality." The site also provides data and information on six research groups: "Aerosols," "Radiation," "Carbon Cycle Gases," "Trace Gases," "Observatory Operations," and "Ozone \& Water Vapor." The site describes how climate is being changed not just through natural processes but also by such mechanisms as "climate forcing" or "man-made pollution, through emissions of greenhouse gases and aerosols. By altering the global energy balance, such mechanisms 'force' the climate to change."

GMD is headquartered in Boulder, Colorado, but maintains five observatories in northern Alaska, Hawaii, northern California, American Samoa, and the South Pole. At these stations, scientists take long-term baseline samples of key elements. The current and historical data is available and can be obtained by FTP directly from the Web site. Users will find data sets on carbon monoxide, carbon dioxide, nitrous oxide, hydrocarbons, aerosols, radiation, methane, water vapor, ozone, and more.

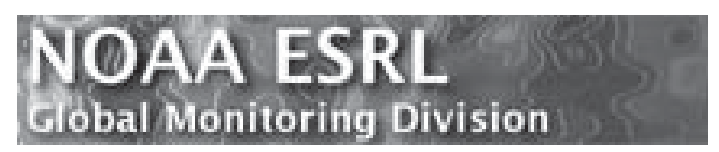

The site itself is well designed and easy to navigate, with many useful charts and graphs that discuss the long-term measurements that demonstrate the changes in our climate. There are links to related agencies, data centers and programs. Users can search the GMD site for content or images using a search engine powered by Google or search an extensive list of GMD publications back to 1992 .

For scientists or students studying climate change, the GMD site is a useful tool with clear explanations and long-term data on this vital topic.-Kate Peterson, St. Cloud State University, jcpeterson@stcloudstate.edu

\section{State of the News Media 2006: An Annual} Report on American Journalism. Access: http://www.stateofthemedia.org/2006 /index.asp.

The Roman satirist Juvenal famously asked the question "But who watches the watchmen?" To twist the phrase a bit, if the news media are viewed as the watchers or the watchdogs of our democracy, who watches over them? This site provides one answer.

Produced by the Project for Excellence in Journalism, an affiliate of the Pew Research Center, this site provides a detailed report on the effectiveness of all aspects of the news media over the past year. This is the third year the report has been issued, and reports from the previous two years are also available.

At more than 178,000 words, the report is divided into 12 chapters. Included are an overview of the report; "A Day in the Life of the Media"; chapters on each form of media (newspapers, online, network television, cable television, local television, magazines, radio, and ethnic and alternative media); a survey of the attitudes and opinions journalists hold regarding their profession; and, finally, a chapter explaining the methodology of the study, information on the authors and collaborators, and a bibliography of the sources used to create the study.

Within each chapter are sections focusing on areas specific to that chapter. As an example, the chapter "A Day in the Life of the Media" selects one day's worth of news coverage-May 11, 2005-to examine in depth. This section is further broken down by news media type (newspaper, online, etc.), which allows a concentrated view of how that specific medium dealt with the news events of that day. Stories covered, strengths in reportage, and bias of reporting are among topics examined.

The chapters dealing with individual media include separate introductions and sections on content analysis, audience, economics, ownership, news investment, public attitude, and charts and tables. All charts and tables, which illustrate the statistical data

(continued on page 524) 
to 1983 he served as head of reference at DePauw University. From 1983 to 1995 he served as director of library services at Eckerd College, and from 1995 to 2004 he served as college librarian at Austin College. He returned to the University of NebraskaKearney in 2004 to serve his alma mater as the dean of the library. Long active in ACRL, Hardesty has served in numerous offices, including on the ACRL Board of Directors (1987-91), chair of the College Libraries Section (1995-96), president of ACRL (1999-2000), and chair of the 11th ACRL National Conference (2003)—which set a record for attendance. As ACRL president, he initiated the Excellence in Academic Libraries Award. He recently ended terms as councilor-at-large on the ALA Council, chair of the ALA Council Resolutions Committee, and chair of the ACRL Task Force on Awards. While at Eckerd College, Hardesty organized five Earlham College-Eckerd College Bibliographic Instruction Conferences held from 1984 to 1992, which resulted in the publication, Bibliographic Instruction in Practice (Pierian Press 1992). His other monographs include Faculty and the Library (Ablex 1991), and Books, Bytes and Bridges (ALA 2001). His article "Faculty Attitudes towards the Library" was published in Library Trends and received ACRL's Instruction Section's Publication of the Year Award in 1995. Hardesty received ACRL's Academic/Research Librarian of the Year Award in 2001. Hardesty is currently editing a book on the library and the first-year experience to be published by the National Center for the First-Year Experience and Students in Transition and to be jointly distributed by the center and ACRL. Hardesty will continue to serve as the founding director the College Library Directors' Mentor program (during the past 14 years he has matched more than 200 first-year college library directors with mentors).

\section{Deaths}

Alan Clark, member of the Woodruff Library staff at Emory University, passed in February 2006 after a long illness. He began his career at Emory in 1972 in a circulation staff position, while working on a Ph.D. in religion. In 1977 he accepted a position as reference librarian. Clark served as acting head of the reference department from the fall of 1994 through the summer of 1995 , leaving the library in 1997. For many years Clark literally served as the voice of the library; his speaking voice was used to record the library's official messages. 72

("The China Mission" cont. from page 507) between academic librarians from the People's Republic of China and the United States was accomplished with great enthusiasm by both delegations. The opportunity for a true world wide web of information was created by the open discussion of academic library issues and ideas, thereby permanently transfiguring the path of Chinese librarianship (in accepting other perspectives on information) and informing American librarians of worldwide advancements in information technologies.

("Internet Reviews" continued from page 517) from the study, are available together in a separate section in addition to their inclusion separately in appropriate chapters.

"Roundtable" is a virtual discussion with industry leaders. Most roundtables are not available, but users may request an e-mail notification when that section is completed.

The site is easy to navigate, with chapter and sections links on each page. It is simple in layout, with an attractive balance of text and image. Recommended for journalism students and others with an interest in "watching the watchdogs." - Ford Schmidt, Willamette University, fschmidt@willamette.edu n 